\title{
SISTEM INFORMASI PENILAIAN KINERJA KARYAWAN BERBASIS WEB PADA PT. HYDRO RAYA ADHI PERKASA
}

\author{
Siti Maesaroh* ${ }^{1}$ \\ Giandari Maulani \\ Nur Asari ${ }^{3}$ \\ ${ }^{1,2 \& 3}$ Program Studi Sistem Informasi Fakultas Sains dan Teknologi Universitas Raharja \\ Email : ${ }^{* 1}$ Siti.maesaroh@ raharja.info, ${ }^{2}$ Giandari@raharja.info, ${ }^{3}$ Nurasari@ raharja.info
}

\begin{abstract}
ABSTRAK
PT. Hydroraya Adhi Perkasa Tangerang adalah perusahaan yang bergerak dibidang konstruksi yang mengerjakan beberapa project besar seperti pengolahan air limbah, minyak dan gas, listrik, air serta sektor industri lainnya secara umum. Sistem saat ini dirasa masih kurang efektif dalam melakukan penilaian kinerja terhadap karyawan. Untuk dapat melakukan penilaian kinerja dengan baik maka diperlukan sistem penilaian kinerja berbasis web untuk mempermudah dalam penilaian kinerja karyawan serta membantu pengolahan data menjadi informas i yang dihasilkan. Pada pembuatan sistem ini menggunakan metode analisa SWOT (Strenght, Weakness, Opportunities, Threats) untuk mengidentifikasi kelemahan sistem menjadi rekomendasi dalam membuat perbaikan-perbaikan yang harus dibuat pada sistem yang harus dikembangkan.
\end{abstract}

Kata kunci: PT. Hydroraya Adhi Perkasa, Penilaian Kinerja, SWOT

\section{ABSTRACT}

PT. Hydroraya Adhi Perkasa Tangerang is a company engaged in construction that works on several large projects such as waste water treatment, oil and gas, electricity, water and other industrial sectors in general. The current system is still considered ineffective in evaluating employee performance. To be able to conduct performance appraisals properly a web-based performance appraisal system is needed to facilitate employee performance appraisal and help processing data into information that is generated. In making this system uses the SWOT analysis method (Strength, Weakness, Opportunities, Threats) to identify system weaknesses into recommendations in making improvements that must be made on the system that must be developed.

Keywords: PT. Hydroraya Adhi Perkasa, Penilaian Kinerja, Swot

\section{Pendahuluan}

Perkembangan teknologi informasi memacu untuk memasuki era modern dalam kehidupan, Kehidupan seperti ini dikenal dengan e-life (electronic life), artinya dalam kehidupan ini sudah dipengaruhi oleh berbagai kebutuhan secara elektronik. Sekarang sedang semarak dengan berbagai huruf yang dimulai dengan awalan e, seperti e-commerce, e-government, e-library, e-journal, e-medicine, e-laboratory, serta yang lainnya lagi yang berbasis elektronik [1] 
ISSN: 2461-1409

Online ISSN: 2655-5298

PT.Hydroraya Adhi Perkasa adalah perusahaan ISO 9001:2008, ISO 9001: 2015, OHSAS 18001:2007, ISO 14000:2015,yang bisnis utamanya adalah desain dan pabrikasi baja. Dengan keahlian dalam perancangan sistem, pemasangan, startup, dan perawatan yang dikombinasikan dengan layanan handal dan cadangan teknis, kami memberikan hasil yang sesuai dengan kebutuhan dan kebutuhan pelanggan Pendekatan berorientasi aplikasinya membantu kami memahami kebutuhan pelanggan denganbaik. Dikombinasikan dengan system quality assurance, memungkinkan menawarkan solusi unik, produk dan layanan berkualitas. Kliennya berkisar dari dunia industri kimia dan petrokimia, konstruksi, pertanian, pertambangan, makanan, dan minuman serta air dan pengolahan air limbah. PT.Hydroraya Adhi Perkasa, karena harus membenahi sistem yang ada, salah satunya yaitu sistem penilaian kinerja karyawan, pada saat ini system penilaian kinerja karyawan di PT.Hydroraya Adhi Perkasa masih dilakukan secara manual. Komputer sangat dibutuhkan untuk membantu menangani penilaian kinerja terhadap karyawan yang bekerja di bidangnya masing-masing.

\section{PERMASALAHAN}

Pemanfaatan SWOT untuk mengetahui permasalahan ataupun suatu topic dari 4 sisi yang berbeda diantaranya, Strength $(\mathrm{S})$ atau disebut sebagai analisis kekuatan, Weaknesses (W) atau disebut sebagai kelemahan, Opportunity (O) atau disebut sebagai analisispeluang, Threats (T) atau disebut sebagaian alisis ancaman. [2]. Karena sistem yang berjalan saat ini masih belum berjalan dengan baik dalam penilaian kinerja karyawan pada PT. Hydroraya Adhi Perkasa bahwa Penilaian kinerja adalah proses mengevaluasi seberapa baik karyawan melakukan pekerjaan mereka dibandingkan dengan seperangkat standard dan kemudian mengkomunikasikan informasi tersebut kepada karyawan.[3].

Berdasarkan permasalahan yang telah dipaparkan diatas maka PT. Hydroraya Adhi Perkasa ini sangat membutuhkan sistem yang mampu mengolah data penilaian kinerja karyawan [4]dan penilaian kinerjasendiri memiliki manfaat terhadap pegawaiyang menyebabkan terpicunya semangat berkompetisi untuk menjadi lebih baik kedepannya. Salah satunya ditandai dengan peningkatan etos kerja para pegawai itu sendiri. Sementara itu bagi organisasi akan berdampak pada adanya peningkatan produktivitas organisasi. [5].

\section{Metode Penelitian}

\subsection{Metode Analisa SWOT}

Analisis SWOT (SWOT analysis) yakni mencakup upaya-upaya untuk mengenali kekuatan, kelemahan, peluang dan ancaman yang menentukan kinerja perusahaan. Informasi eksternal mengenai peluang dan ancaman dapat diperoleh dari banyak sumber, termasuk pelanggan dokumen pemerintah, pemasok, kalanganperbankan, rekan diperusahaan lain.[6].

Bentuk analisa di dalam manajemen suatutempat atau suatu perkumpulan yang secara teratur dapat membantu dalam penyusunan suatu rencana untuk memenuhi suatu tujuan yang sudah ditetapkan. Analisa SWOT berisi 4 Komponen dasar yang terdiri dari. Strength (Kekuatan), Weakness (Kelemahan), Opportunity (Peluang), Threat (Hambatan) [2].

\subsection{Metode Pengumpulan Data}

Untuk mendapatkan data yang diperlukan dalam penelitian, peneliti menggunakan beberapa metode sebagai berikut:

1. Metode Pengamatan Langsung (Observasi) 
ISSN: 2461-1409

Online ISSN: 2655-5298

Peneliti dating langsung ke PT.Hydroraya Adhi Perkasa untuk pengamatan langsung terhadap sistem yang sudah berjalan dan menganalisis secara sistematis terhadap unsur - unsur yang diteliti

2. Metode Wawancara (Interview)

Peneliti melakukan proses Tanya jawab secara langsung kepada pihak yang bersangkutan dalam proses pelayanan sistem pembuatan surat pengantar yang sedang berjalan saat ini untuk mendapatkan informasi yang akurat dan untuk menyelesaikan penelitian ini.

3. Studi Pustaka (LibraryPustaka)

Dilakukan dengan mencari dan membaca beberapa referensi dari perpustakaan dan internet untuk mendapatkan informasi atau sumber- sumber kajian yang terkait dengan penelitian ini.

\subsection{Metode Perancangan}

Metode Perancangan Sistem dapat didefinisikan sebagai penggambaran, perencanaan dan pembuatan sketsa atau pengaturan dari beberapa elemen yang terpisah kedalam satu kesatuan yang utuh dan berfungsi [7] yaitu dengan menggunakan UML, UML merupakan sintesis dari tiga metode analisis dan perancangan berbasis objek serta ditambah dengan keunggulan metodemetode berorientasi objek lainnya (fushion, shlaer-mellon, coad-yourdom) yang juga disintesiskan dalam UML menawarkan pendekatan yang cukup baik yang sudah digunakan di industry perangkat lunak, kemudian di database server dimana pemrosesan data terjadi deserver dan client hanya mengirim data serta meminta data. [8] Oleh karena pemrosesan terjadi diserver sehingga pengaksesan data tidak terbatas [9] dan salah satu paket instalasi apache, PHP dan MySQL secara instan yang dapat digunakan untuk membantu prosesi nstalasi ketiga produk tersebut menggunakan Xampp.[10]

\section{Hasil danPembahasan}

4.1 Rancangan Sistem: Activity Diagram

1. Activity Diagram Pada Sistem Penilaian Kinerja Karyawan

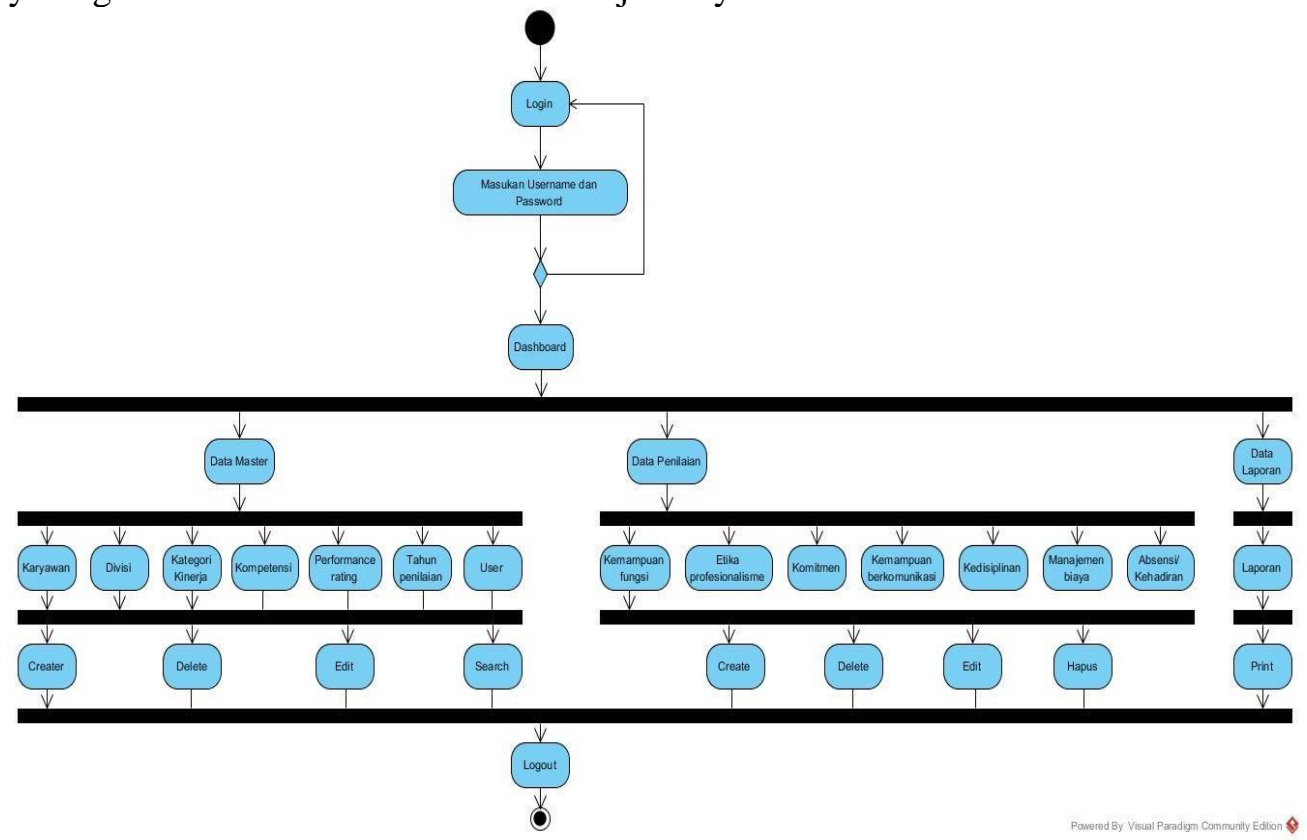

Gambar 1.Activity Diagram Sistem Sistem Penilaian Kinerja Karyawan 
ISSN: 2461-1409

Online ISSN: 2655-5298

Berdasarkan gambar 1. Activity Diagram diatas terdapat: Initial Node, objek yang diawali Action dari system yang mencerminkan eksekusi.

2. Activity Diagram Pada Admin

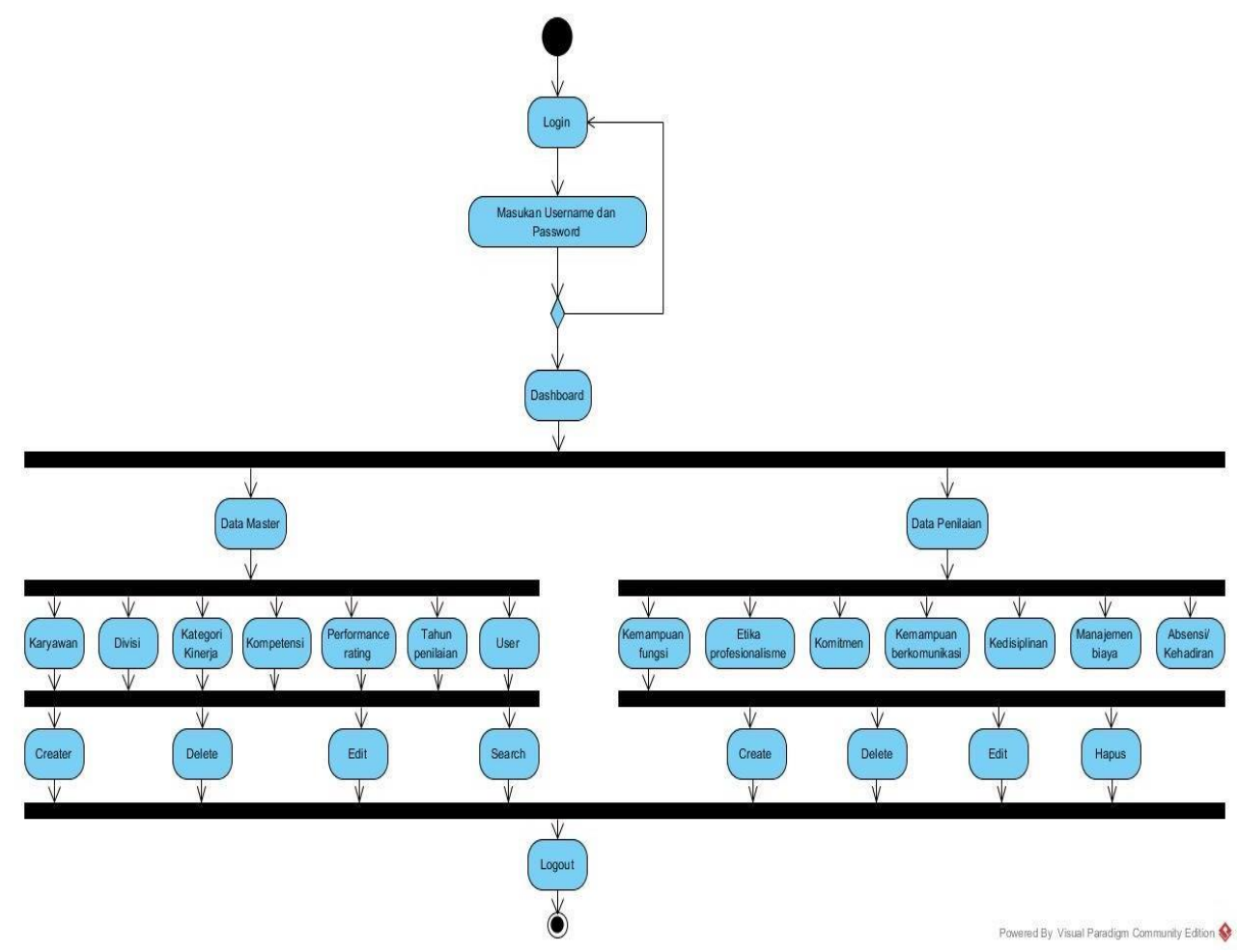

Gambar 2.Activity Diagram Pada Admin

Berdasarkan Gambar 2 Activity Diagram Pada Admin diatas terdapat: 1 Initial Node objek yang diawali 28 Action dari system yang mencerminkan eksekusi dari suatu aksi. 1 Decision Node, yaitu node yang menunjukan pilihan akan suatu kondisi tertentu, yang menghasilkan suatu kemungkinan. Fork Node merupakan node untuk membagi satu action menjadi beberapa action. 1 Activity Final Node merupakan node objek yang diakhiri.

3. Activity Diagram Pada Manager 
ISSN: 2461-1409

Online ISSN: 2655-5298

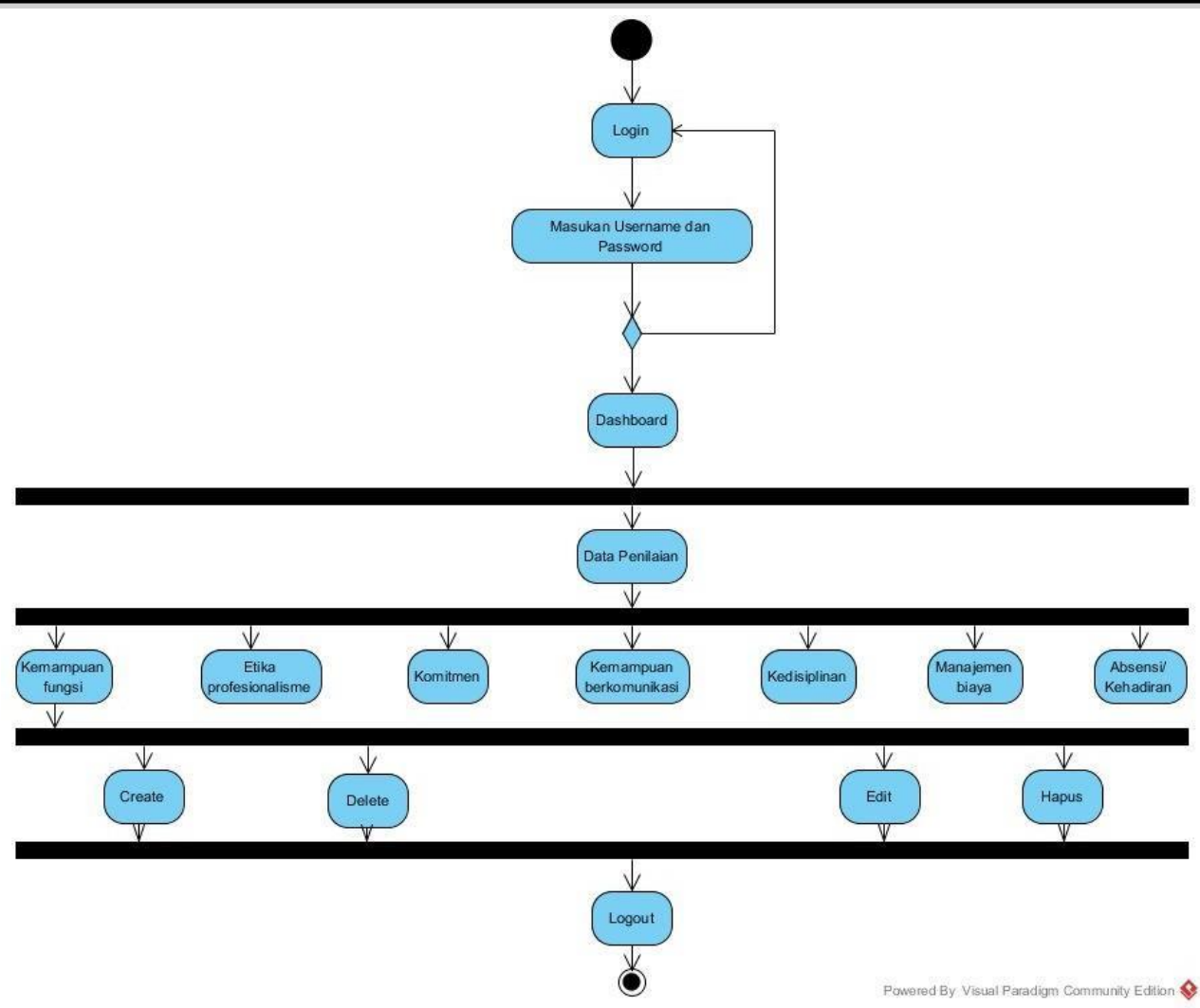

Gambar 3. Activity Diagram Pada Manager

Berdasarkan Gambar 3 Activity Diagram Sistem yang diusulkan terdapat penjelasan sebagai berikut :1 Initial Node, objek yang diawali, 16 Action dari system yang mencerminkan eksekusi dari suatu aksi. 1 Decision Node, yaitu node yang menunjukan pilihanakan suatu kondisi tertentu, yang menghasilkan satu kemungkinan, 1 Fork Node, merupakan node untuk menggabungkan satu action menjadi beberapa action dan 1 Activity Final Node, objek yang diakhiri.

4. Activity Diagram Pada HRD 
ISSN: 2461-1409

Online ISSN: 2655-5298

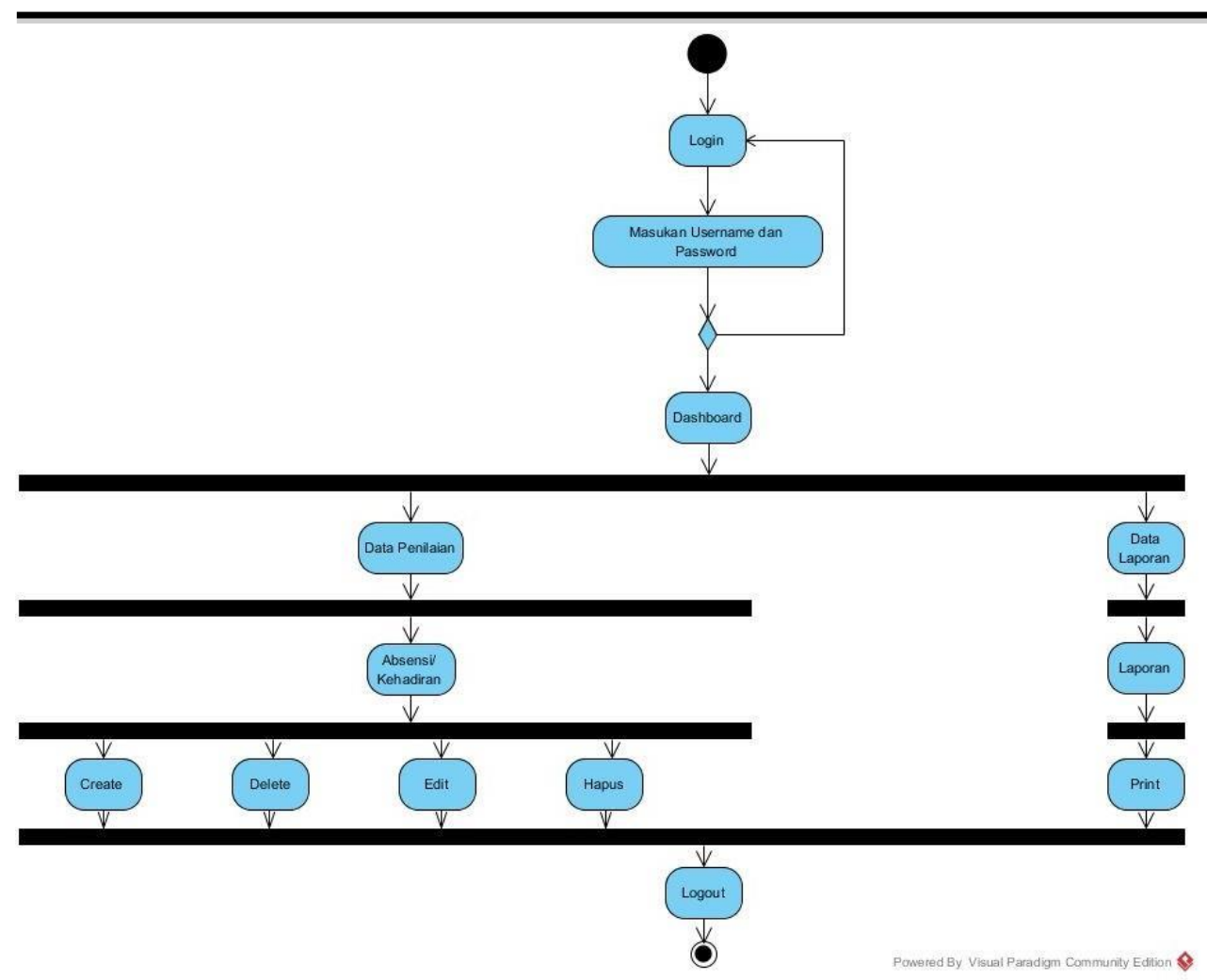

Gambar 4. Activity Diagram Pada HRD

Berdasarkan gambar 4A ctivity Diagram Pada system HRD terdapat: 1 Initial Node, objek yang diawali, 13 Action dari system yang mencerminkan eksekusi dari suatu aksi. 1 Decision Node, yaitu node yang menunjukan pilihan akan suatu kondisi tertentu, yang menghasilkan satu kemungkinan dan 2 Fork Node, merupakan node untuk menggabungkan satu action menjadi beberapa action serta 1 Activity Final Node, objek yang diakhiri.

\subsection{Perancangan Database: Class Diagram}


ISSN: 2461-1409

Online ISSN: 2655-5298

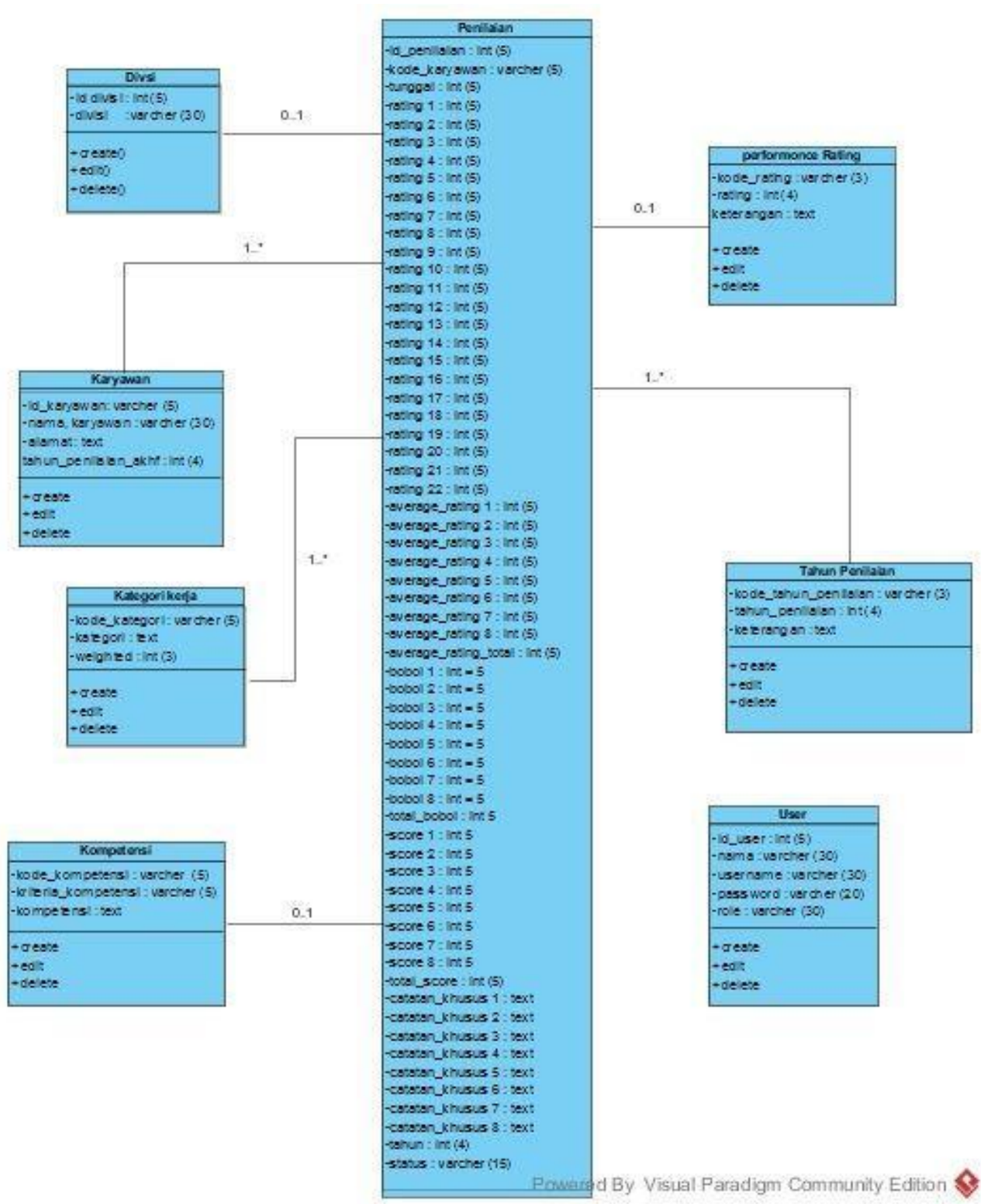

Gambar 5. Class Diagram

Berdasarkan gambar 5 Class Diagram diatas terdapat 8 Class himpunan dari objek berbagai atribut serta operasi yang sama, diantaranya yaitu divisi, penilaian, karyawan, kategori kerja, kompetensi, performance rating, tahun penilaian dan user dan 1 Multiciply, hubungan antara objek satu dengan yang lainnya

\subsection{Implementasi Sistem Program}

1. Tampilan Login 
ISSN: 2461-1409

Online ISSN: 2655-5298

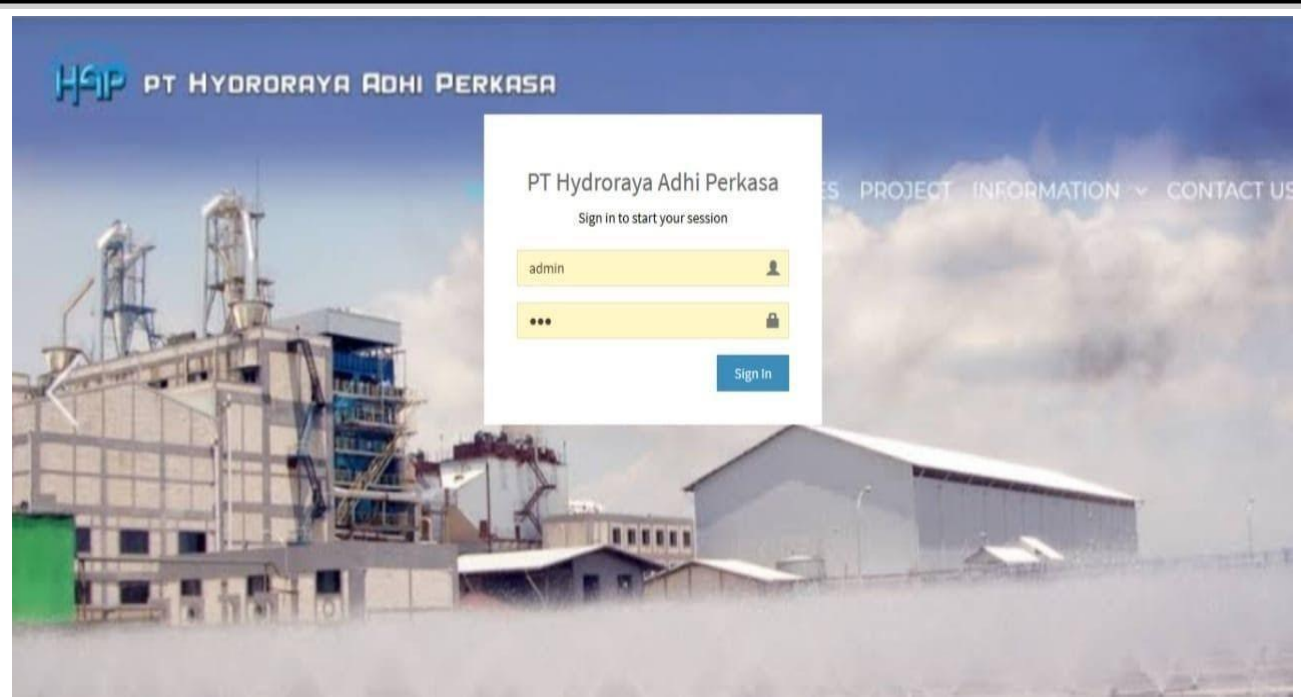

Gambar 6. Tampilan Login Sistem

Tampilan diatas merupakan tampilan halaman login atau tampilan awal sebelum masuk kedalam sistem. Setia puser harus melakukan login terlebih dahulu dengan menginput username dan password.

2. Tampilan Halaman Menu Data Karyawan

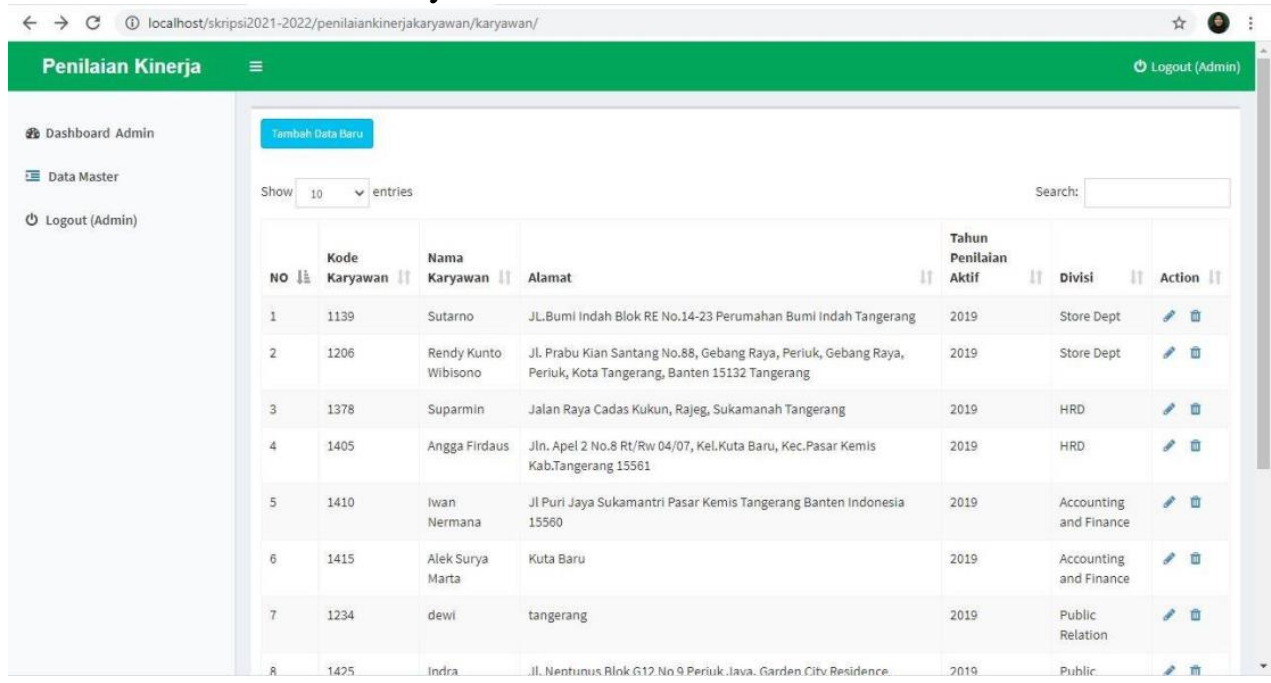

Gambar 7. Tampilan Halaman Menu Data Karyawan 
ISSN: 2461-1409

Online ISSN: 2655-5298

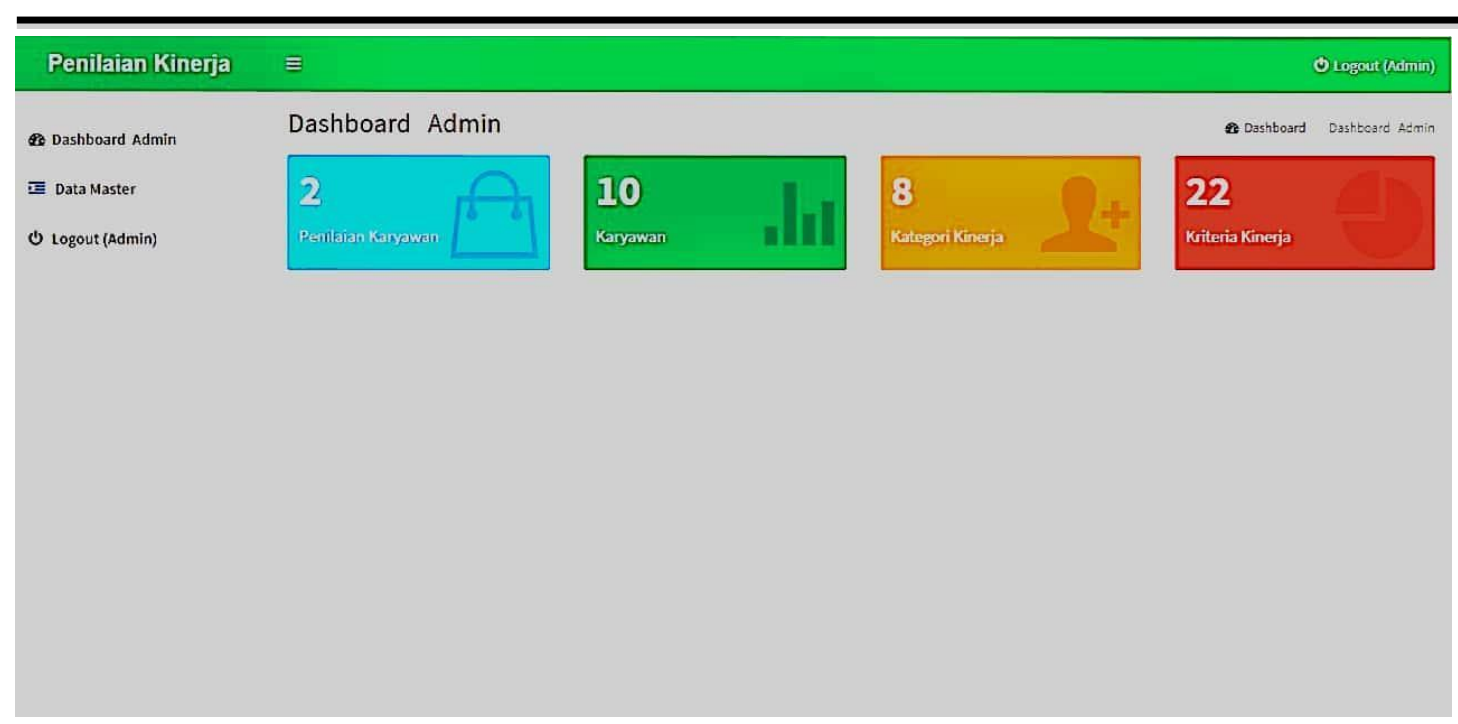

Gambar 8. Tampilan Halaman Menu Data Karyawan

Tampilan diatas merupakan tampilan menu data karyawan yang telah di input ke dalam sistem dengan memasukkan nik, nama dan tempat tinggal.

3. Tampilan Menu Divisi

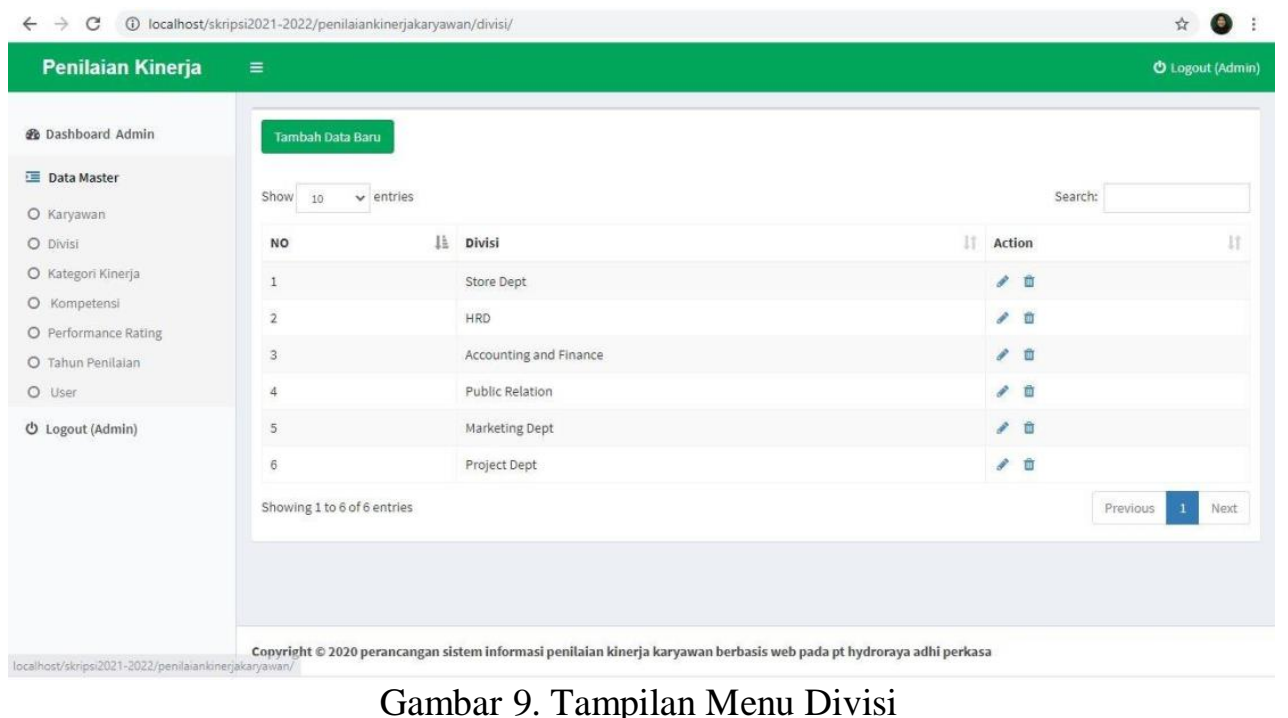

Berdasarkan gambar 9. Tampilan Menu Divisi Tampilan diatas merupakan tampilan menudata divisi yang telah di input kedalam sistem dengan memasukkan divisi.

4. Tampilan Kategori Kinerja 
ISSN: 2461-1409

Online ISSN: 2655-5298

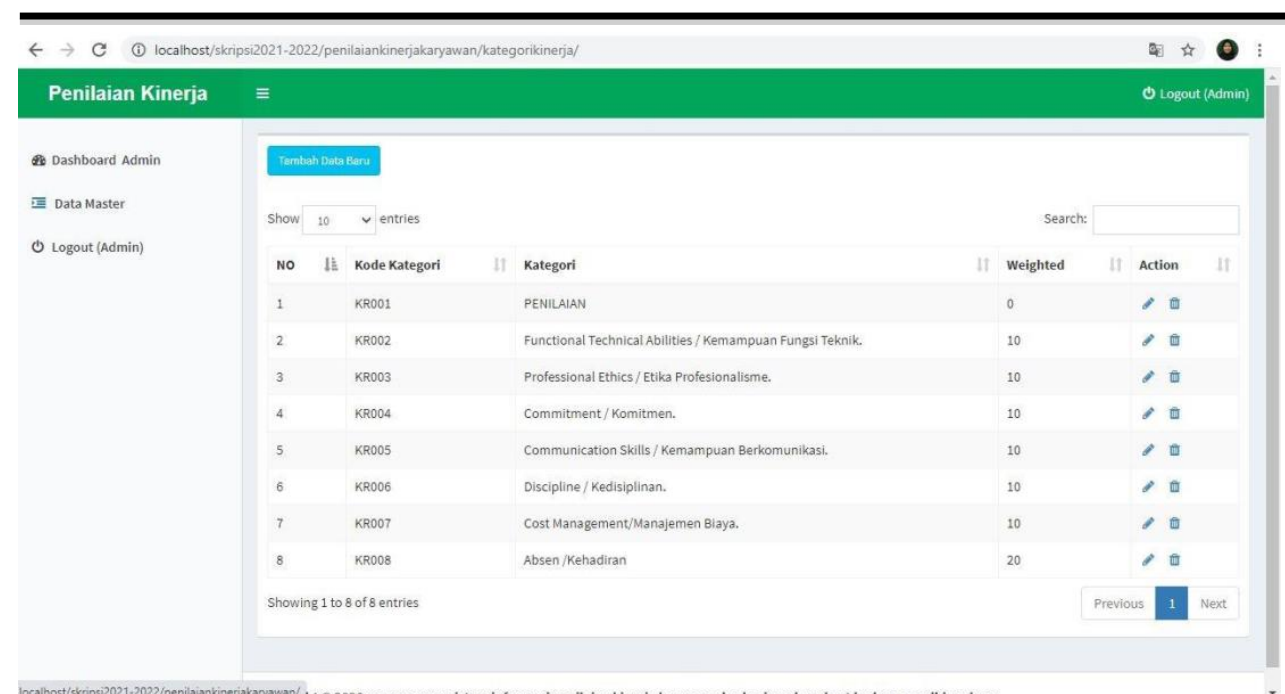

Gambar 10. Tampilan Kategori Kinerja

Berdasarkan gambar 10. Tampilan Tampilan diatas merupakan tampilan halaman menu kategori kinerja yang di dalamnya terdapat bobot persentase dari setiap kategori masing-masing.

5. Tampilan Halaman Menu Kompetensi

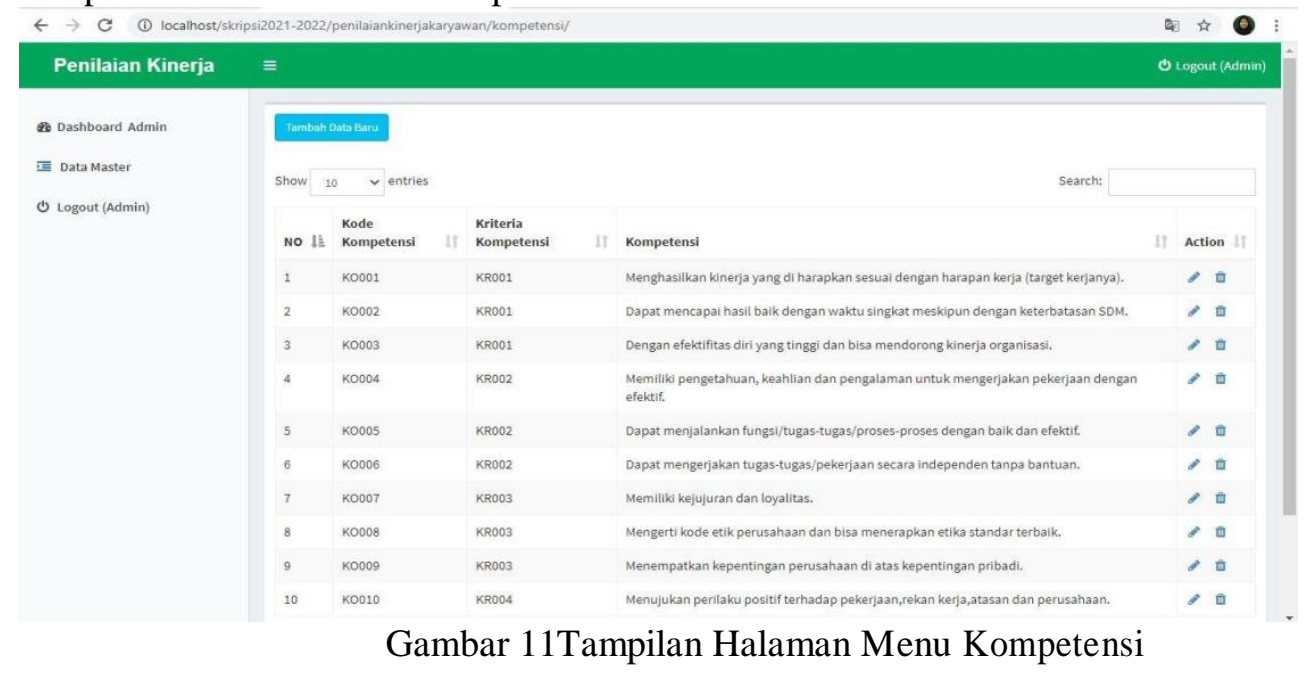

Tampilan diatas merupakan tampilan menu kompetensi penilaian,berisikan kompetensi apa saja yang harus dinilai oleh manager atau hrd kepada karyawan.

6. Tampilan Halaman Menu Performance Rating 
ISSN: 2461-1409

Online ISSN: 2655-5298

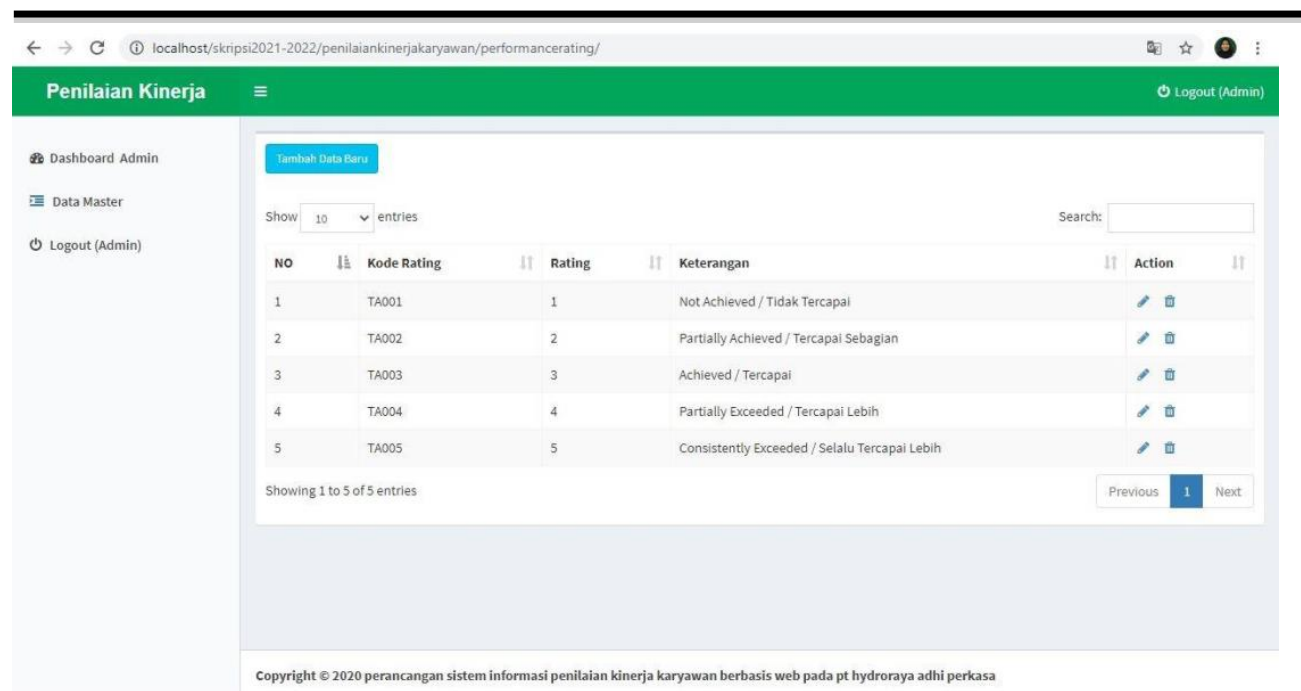

Gambar 12 Tampilan Halaman Menu Performance Rating

Tampilan diatas merupakan halaman tampilan rating penilaian yang berisikan jumlah point minimum penilaian, maksimum penilaian dan juga berisikan keterangan dari point penilaian.

7. Tampilan Halaman Menu Tahun Penilaian

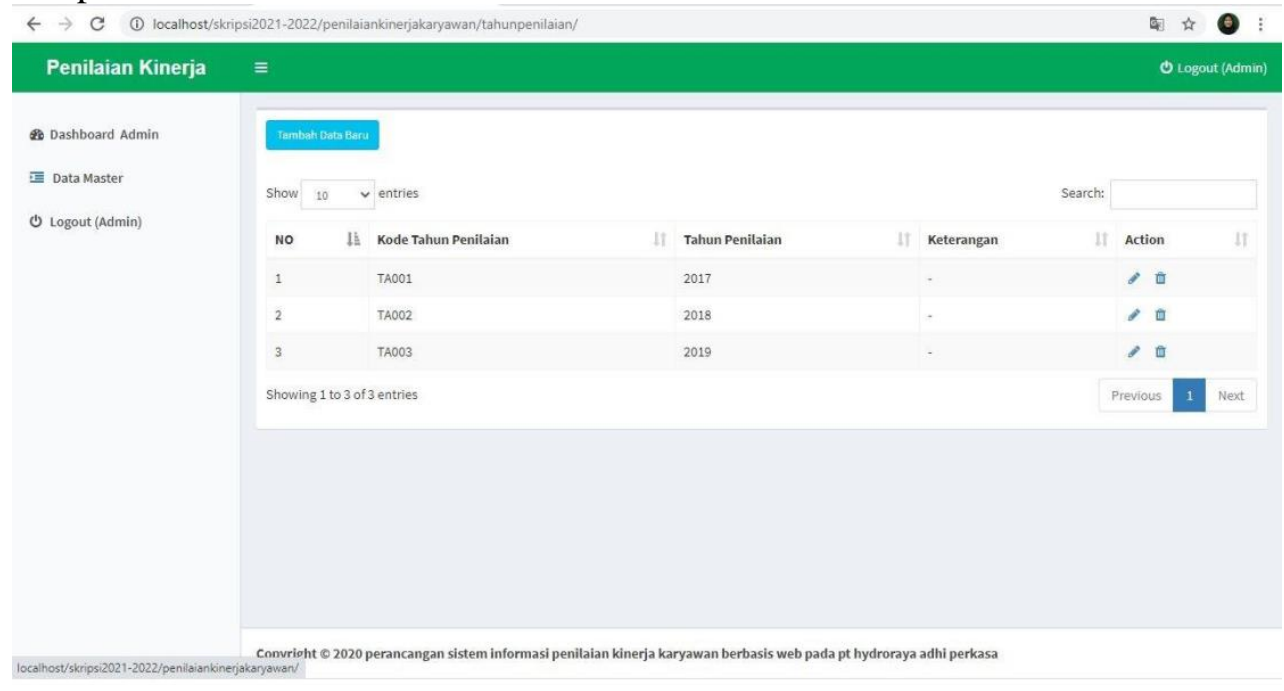

Gambar 13.Tampilan Menu Tahun Penilaian

Tampilan diatas merupakan tampilan dari halaman tahun penilaian, dimana admin memiliki akses untuk menambahkan tahun penilaian atau mendaftarkan tahun penilaian untuk karyawan yang akan dinilai.

8. Tampilan Halaman Menu User 
ISSN: 2461-1409

Online ISSN: 2655-5298

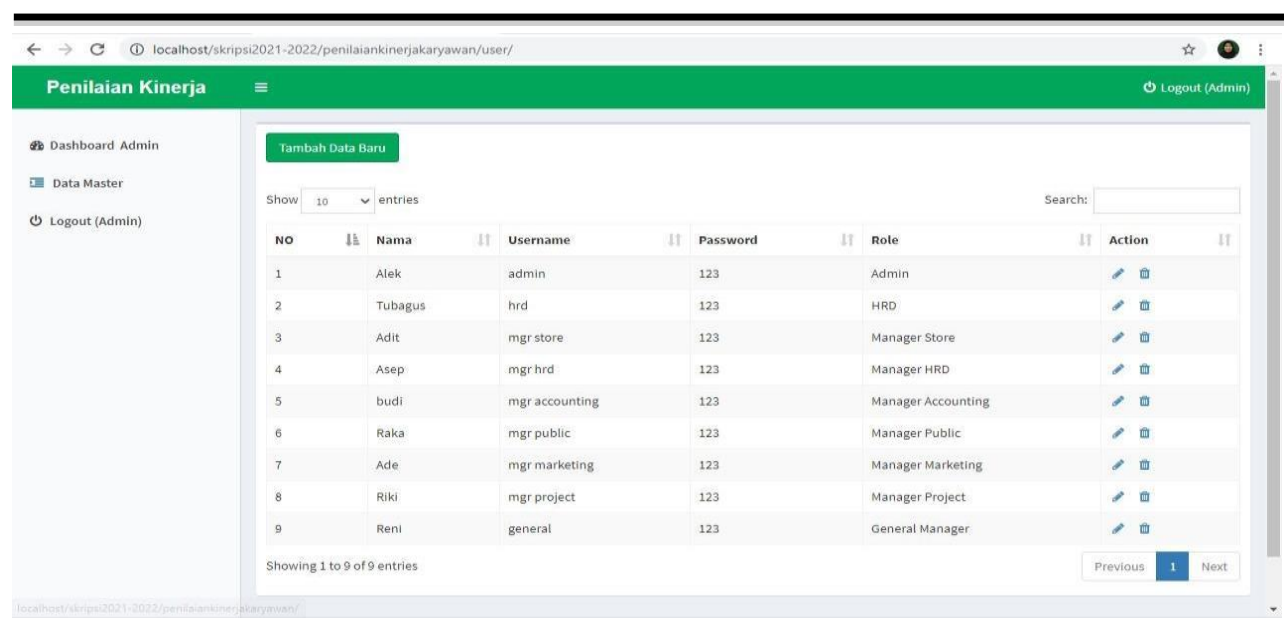

Gambar 14 Tampilan Halaman Menu User

Tampilan diatas merupakan tampilan menu user akses pada system penilaian kinerja karyawan, admin dapat menambahkan, menghapus ataupun mengedit akses user.

9. Tampilan Halaman Menu Tambah Data Karyawan

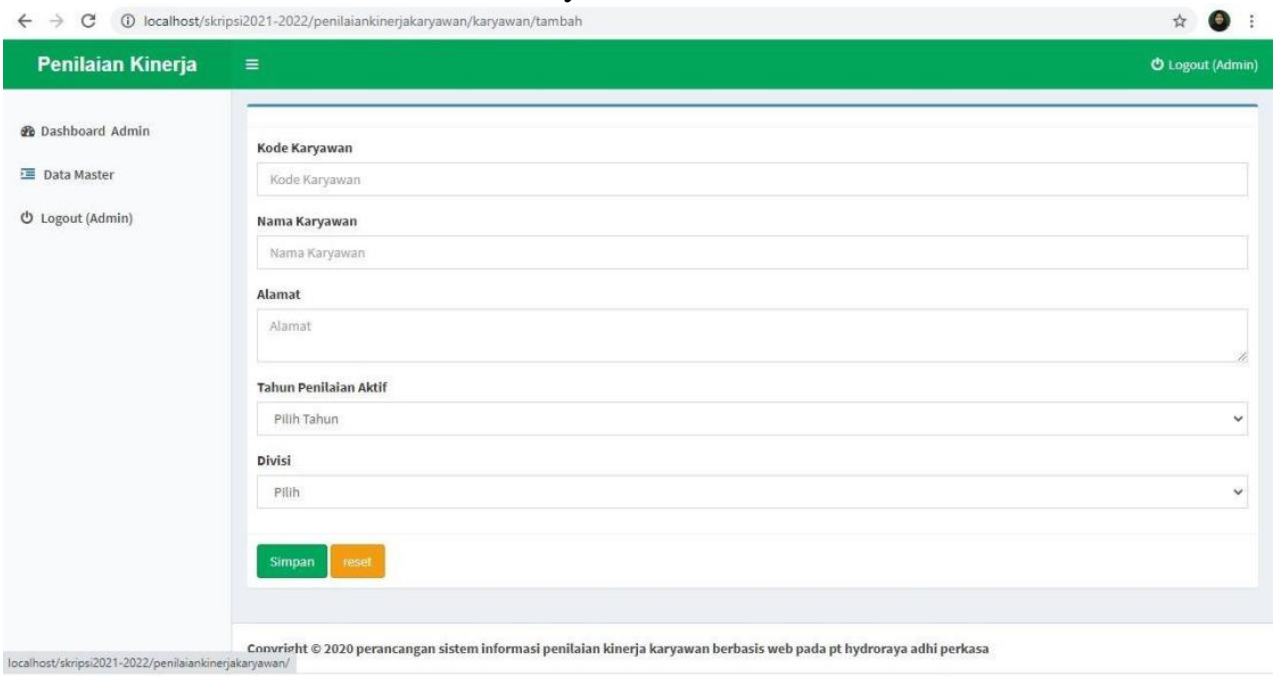

Gambar 15 Tampilan Halaman Menu Data Penilaian

Tampilan diatas merupakan tampilan halaman menu data penilaian yang sudah dinilai oleh manager.

10. Tampilan Halaman Menu Data Penilaian Absensi 


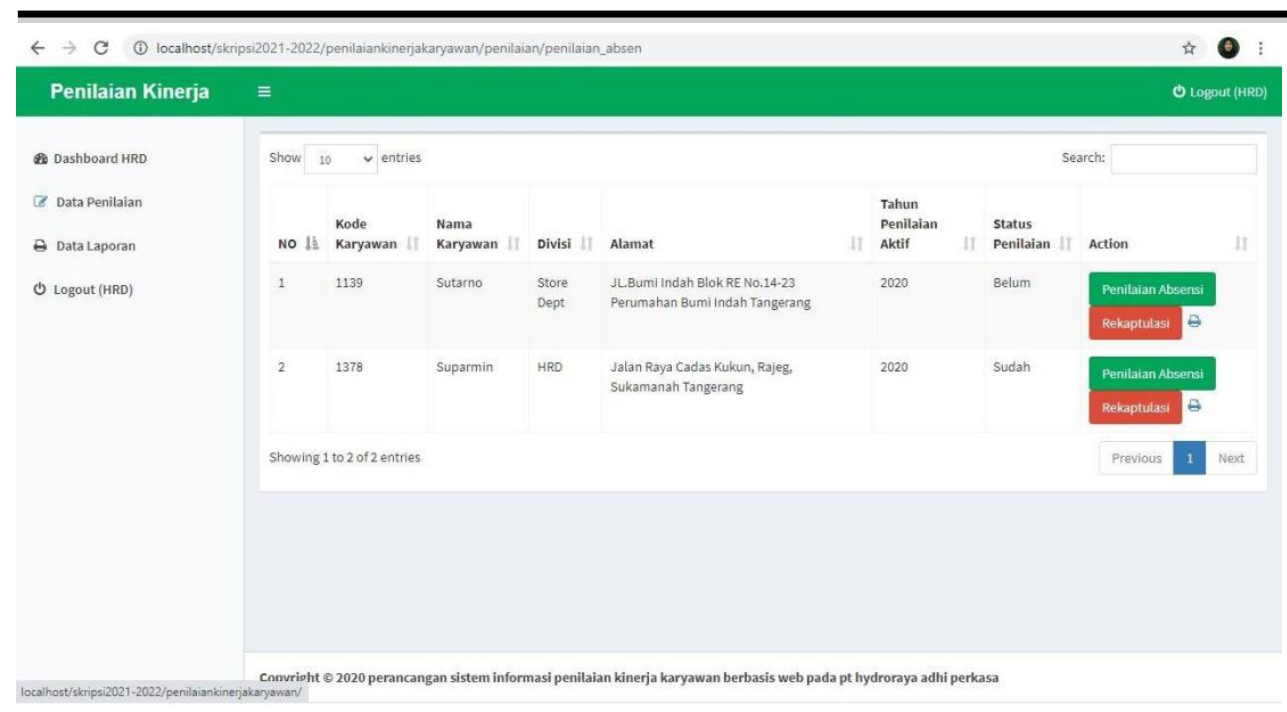

Gambar15.Tampilan Halaman Menu Data Absensi

Tampilan diatas merupakan tampilan dari data absensi yang telah di input atau yang sudah dinilai oleh HRD.

11. Tampilan Halaman Menu Data Laporan

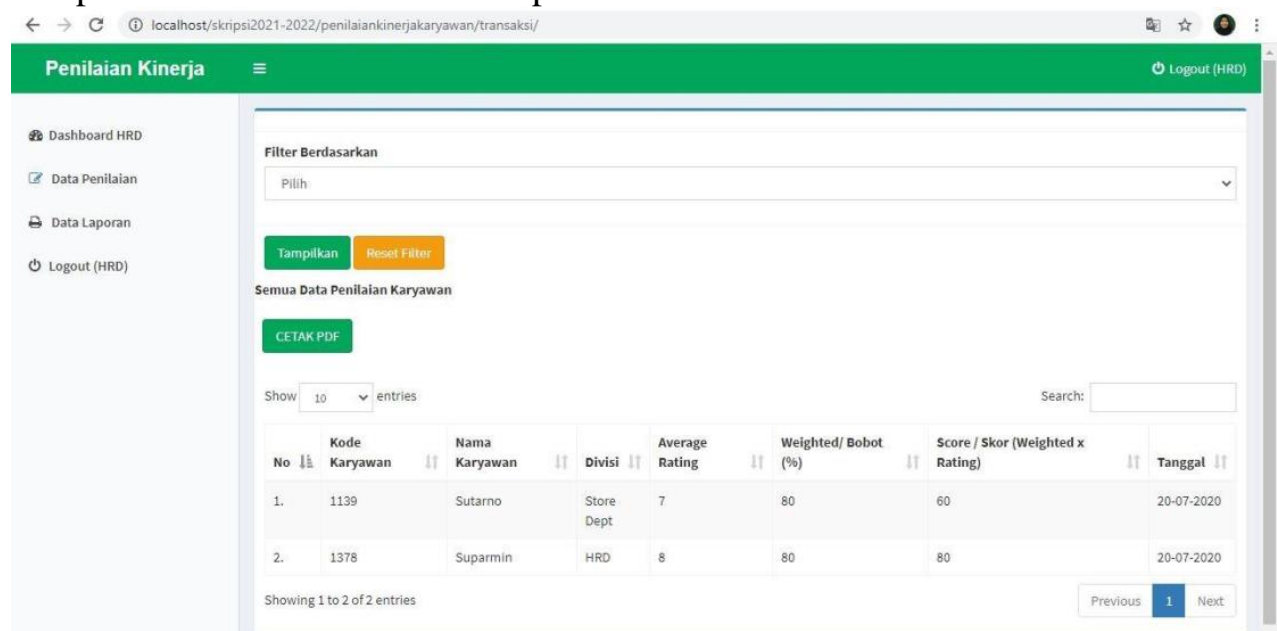

Gambar 16.Tampilan Halaman Menu Data Laporan

Tampilan diatas merupakan tampilan dari menu data laporan yang sudah dinilai dan dapat di cetak/print

\section{Kesimpulan}

Berdasarkan hasil penelitian yang dilaksanakan pada PT. Hydroraya Adhi Perkasa mengenai perancangan system informasi penilaian kinerja karyawan dapat disimpulkan bahwa: Sistem penilaian kinerja karyawan masih manual dalam sehingga prosesnya yang cukup lambat dan masih cenderung banyak salah dalam penulisan dan penilaian analisa hasil survey masih subjektif. Kendala yang dihadapi pada sistem penilaian yang berjalan saat ini yaitu adanya kesalahan perhitungan data nilai dan butuh waktu yang cukup lama dalam pencarian data. Adapun system yang peneliti rancang dengan menggunakan sistem berbasis web dapat melakukan penilaian kinerja secara sistematis dan akurat. 


\section{DaftarPustaka}

[1] S. Maesaroh, D. Rifai \& D. Syafirah Dewi "Perancangan Aplikasi E-Contract Pada Platform Manga Toon Berbasis Web Pada Manga Toon HK Limited" SENSI JOURNAL, Vol. 6 No. 2, PP 148-161 2020

[2] Basuki, Rokhman., Aziz Fathoni, dan Maria Magdalena Minarsih. 2018. Pengembangan Kinerja Sumber Daya Manusia di Honda Semarang Center Berdasarkan Analisis SWOT. Journal of Management. Volume 4 Nomor 4 2018: 1-15.

[3] Rani, Indria Hangga dan Mega Mayasari. 2015. "Pengaruh Penilaian Kinerja Terhadap Kinerja Karyawan Dengan Motivasi Sebagai Variabel Moderasi." Jurnal Akuntansi, Ekonomi dan Manajemen Bisnis, Vol.3 No.2 Hal: 164-170.

[4] Kim, J. (2016). Impact of Performance Appraisal Justice on the Effectiveness of Pay-for-Performance Systems After Civil Service Reform.International Journal Public personnel management Vol. 45 No.2.

[5] Budiharjo, M. 2015. Panduan Praktis Penilaian Kinerja Karyawan. Jakarta: Raih Asa Sukses.

[6] Nisak Zahrutuk Nisak, 2015:3, “Analisis SWOT Untuk Menentukan Strategi Kompetitif”, Malang

[7] Mulyati, Sri. 2018. Analisa Dan Perancangan Sistem Informasi Manajemen Keuangan. Bandung : Abdi Sistematika.

[8] Maulani, Giandari, Devi Septiani, Putri Noer Fauziyah Sahara. 2018. Rancang Bangun Sistem Informasi Inventory Fasilitas Maintenance Pada PT. PLN (Persero) Tangerang. Jurnal ICIT. ISSN :2356-5195. Vol. 4 No. 2. Agustus 2018

[9] Miranthy F. Takalelumang, Yaulie D.Y. Rindengan, Alwin Sambul. (2018) "Aplikasi E-Agri Kabupaten Minahasa Selatan." Vol 13, No 1

[10] Tamando, H. Sitohang., (2018). Sistem Informasi Pengagendaan Surat Berbasis Web Pada Pengadilan Tinggi Medan. Journal Of Informatic Pelita Nusantara Vol. 3 No. 1 (2018:7) 